Images in...

\title{
Septic arthritis of the left hip with striking radiological findings
}

\author{
David Gareth Roberts, Nick Boyce Cam, Aneil Shenolikar \\ Trauma and Orthopaedics Department, Huddersfield Royal Infirmary, Huddersfield, West Yorkshire, UK \\ Correspondence to Dr David Gareth Roberts, DGRoberts08@doctors.org.uk
}

\section{DESCRIPTION}

A 30-year-old female patient presented to casualty with a 3 -week history of left groin and abdominal pain, general malaise and fever. Of note, she was 18 weeks pregnant and had a history of intravenous drug abuse. On clinical examination, the patient was in septic shock and her abdomen was globally tender with guarding. There was

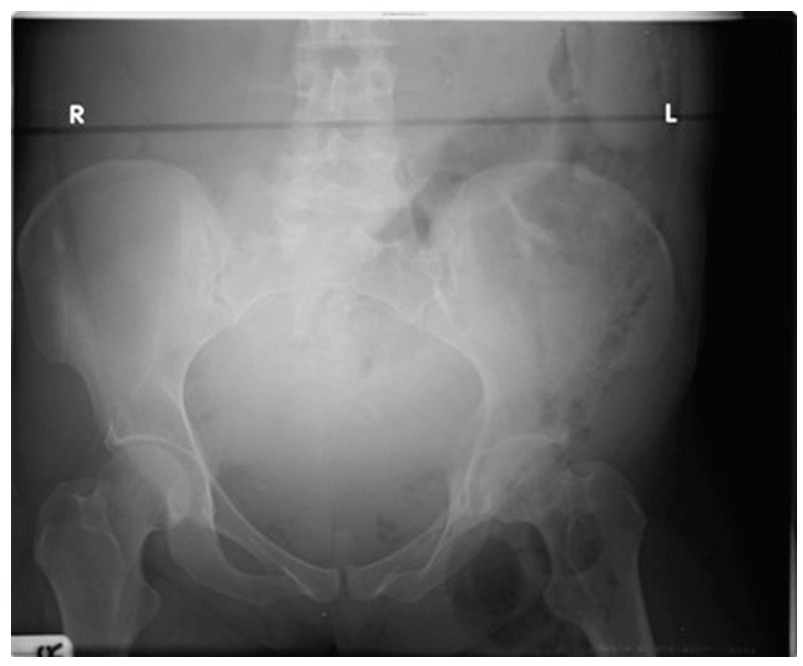

Figure 1 The abdominal radiograph, showing gas in the left lower abdomen and groin.

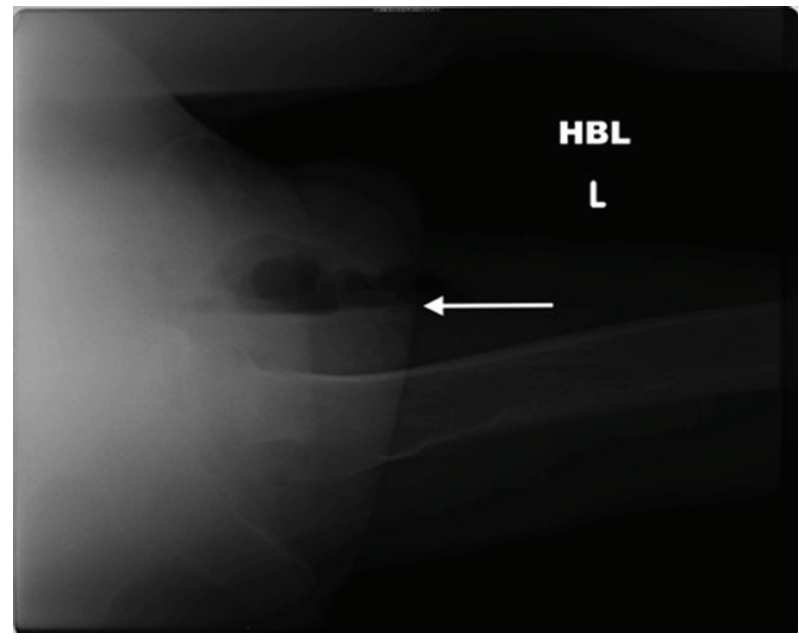

Figure 2 The lateral radiograph of left hip, showing a fluid level and gas in the soft tissues. no palpable hernia or mass with in the groin, however, she had bilateral dry sinuses in the femoral triangles and raised haematological infection markers. The initial abdominal radiograph (figure 1) showed gas over the region of the left groin. Radiographs of the left hip, including a lateral (figure 2), revealed a fluid level above the hip joint with gas superiorly. This raised the concern of underlying suppurative infection and an urgent CT scan was arranged (figure 3). This demonstrated an extensive retroperitoneal collection extending from the origin of the psoas to the left hip and changes within the left femoral head.An emergency operation was performed where copious pus and necrotic tissue were debrided from the left hip, groin and lower abdomen. The left femoral head was necrotic, which required a Girdlestone's procedure (figure 4). After several further operations and a prolonged spell in the intensive therapy unit, the patient is making a good recovery. There are multiple complications arising from parental drug use, some of which have severe consequences and are often diagnostically challenging. ${ }^{1}$ Diseases of the skin and soft tissues are the most common causes of hospital admission with complications including thrombosis, septic arthritis and necrotising fasciitis. ${ }^{2}$

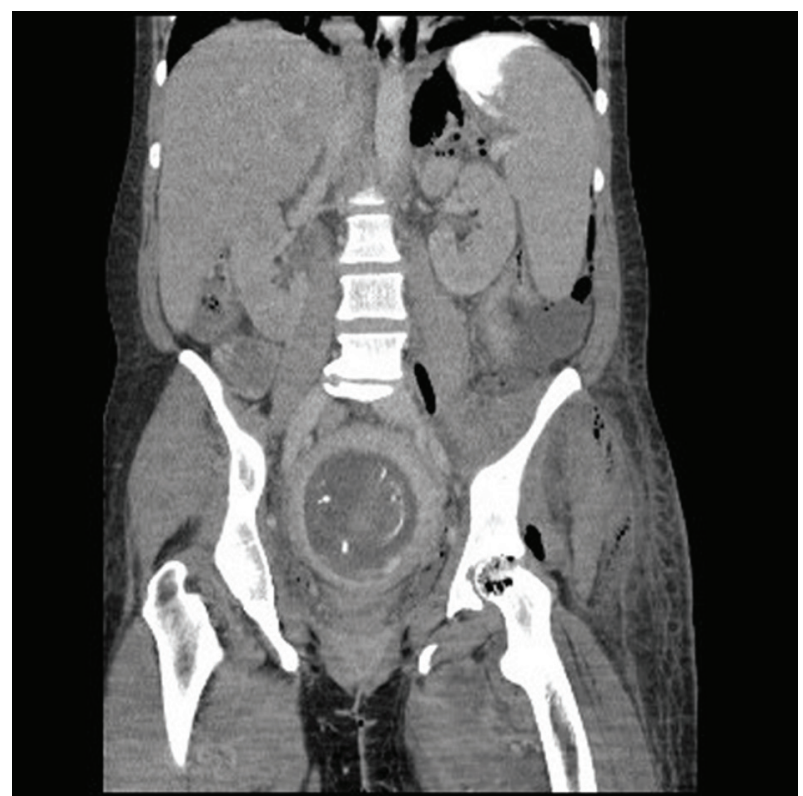

Figure 3 A coronal image of the abdominal CT, showing evidence of bony destruction in the head of the left femur. 


\section{BMJ Case Reports}

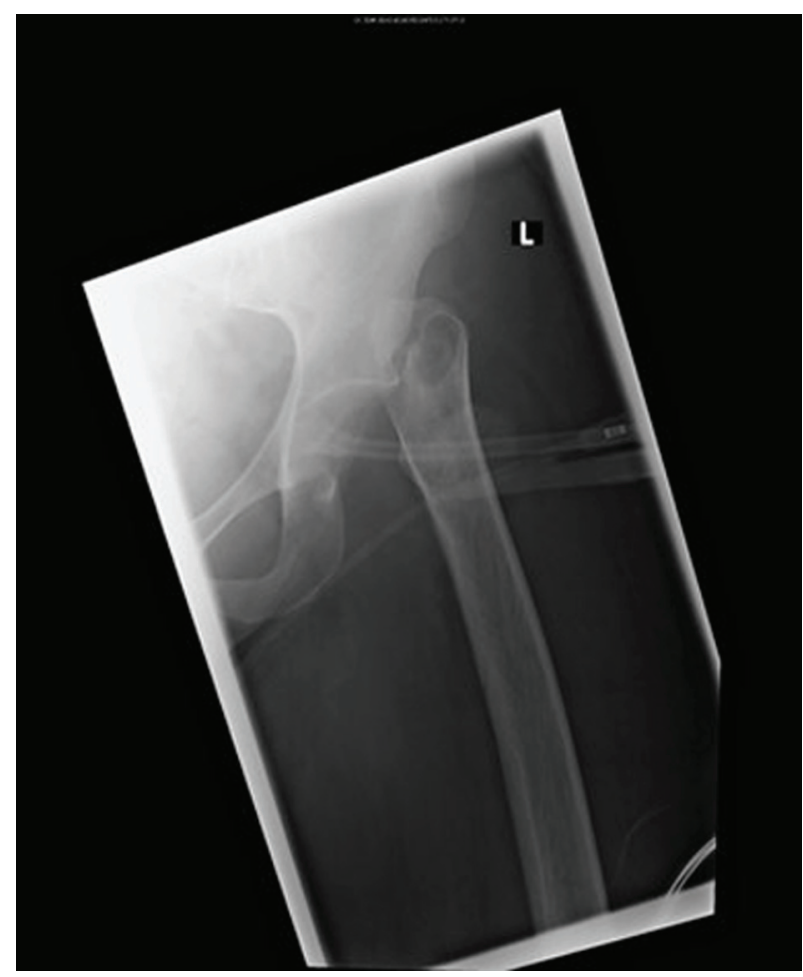

Competing interests None.

Patient consent Obtained.

\section{REFERENCES}

1. Calder KK, Severyn FA. Surgical emergencies in the intravenous drug user. Emerg Med Clin North Am 2003;21:1089-116.

2. Pfefferkorn U, Viehl CT, Bassetti S, et al. Injection site abscesses in intravenous drug users. Frequency of associated complications related to localisation. Chirurg 2005;76:1053-7.

Figure 4 Anteroposterior radiograph of the left hip after Girdlestone's operation.

This pdf has been created automatically from the final edited text and images.

Copyright 2011 BMJ Publishing Group. All rights reserved. For permission to reuse any of this content visit http://group.bmj.com/group/rights-licensing/permissions.

BMJ Case Report Fellows may re-use this article for personal use and teaching without any further permission.

Please cite this article as follows (you will need to access the article online to obtain the date of publication).

Roberts DG, Boyce Cam N, Shenolikar A. Septic arthritis of the left hip with striking radiological findings. BMJ Case Reports 2011;10.1136/bcr.06.2011.4302, date of publication

Become a Fellow of BMJ Case Reports today and you can:

- Submit as many cases as you like

- Enjoy fast sympathetic peer review and rapid publication of accepted articles

Access all the published articles

- Re-use any of the published material for personal use and teaching without further permission

For information on Institutional Fellowships contact consortiasales@bmjgroup.com

Visit casereports.bmi.com for more articles like this and to become a Fellow 